E-ISSN. 2685-7650

Vol 3 No 2 (2021) pp 129-139

Artikel Disubmit 24 November 2021 • Revisi 6 Desember • Revisi Diterima 7 Desember

\title{
Strategi Segmenting, Targeting dan Positioning dalam Membentuk Brand Image Kafe Pan Java
}

\author{
Herru Prasetya Widodo ${ }^{1}$, Mira Maryama ${ }^{2}$ \\ ${ }^{1,2}$ Program Studi Ilmu Komunikasi, Universitas Tribhuwana Tunggadewi \\ Email: herru_prasetyawidodo@yahoo.com
}

\begin{abstract}
Marketing is the main activity carried out to maintain business benefit, develop, and receive. Therefore, to attract consumers to make purchases, business people must be able to implement STP (Segmenting, Targeting, Positioning) strategy. This study aims to determine the segmenting, targeting, and positioning strategies used by Pan Java Cafe in forming a brand image. The method used in this research is descriptive qualitative, with data collection through interview and documentation. Then the data are analyzed using data reduction, data presentation and drawing conclusion. The results shows that the Pan Java strategy segmentation is based on Demographic, Psychographic and Behavioral segmentation. In the targeting strategy, Pan Java Cafe sets a target, where only the marketing team is in the upper middle class community such as Civil Servant (PNS), student, teacher, lecturer, and tourist. Meanwhile, Pan Java's strategic positioning positions its business as a tourist village or cafe that offers a place with a different, unique, comfortable, and safe atmosphere. Currently, Pan Java has formed a brand image as a cafe which is made up of local products.
\end{abstract}

Keywords: marketing; STP strategy; brand image

\begin{abstract}
Abstrak: Pemasaran adalah kegiatan utama yang dijalankan untuk mempertahankan kelangsungan bisnis, mengembangkan dan menerima manfaat. Oleh sebab itu, untuk menarik minat konsumen agar melakukan pembelian, pebisnis harus mampu menerapkan strategi STP (Segmenting, Targeting, Positioning). Penelitian ini bertujuan untuk mengetahui strategi segmenting, targeting, dan positioning yang dilakukan Pan Java Cafe dalam membentuk brand image. Metode yang digunakan dalam penelitian ini adalah kualitatif deskiptif, dengan teknik pengumpulan data melalui wawancara dan dokumentasi. Data kemudian dianalisis menggunakan reduksi data, penyajian data dan penarikan kesimpulan. Hasil penelitian menunjukkan bahwa strategi segmenting Pan Java didasarkan pada segmentasi Demografis, Psikografis dan Perilaku. Pada strategi targeting, Pan Java Cafe menetapkan sasaran terkonsentrasi, di mana hanya memusatkan pemasaran pada kelompok masyarakat menengah ke atas yaitu seperti Pegawai Negeri Sipil (PNS), mahasiswa, pelajar, guru, dosen, keluarga dan para wisatawan. Sementara pada strategi positioning Pan Java memposisikan bisnisnya sebagai desa wisata atau cafe yang menawarkan tempat dengan suasana yang berbeda, unik, nyaman, sejuk dan aman. Saat ini Pan Java membentuk brand image sebagai cafe yang mengedepankan produk-produk lokal.
\end{abstract}

Kata Kunci: pemasaran; strategi STP; brand image

\section{Pendahuluan}

Bisnis menjadi salah satu upaya perbaikan kualitas ekonomi. Tidak heran banyak negara berupaya meningkatkan peluang dan kualitas bisnis yang baik di negaranya. Indonesia sendiri menjadi salah satu negara yang menjadikan bisnis sebagai salah satu aspek peningkatan kualitas ekonomi. Ini disebabkan oleh peluang kerja yang minim sehingga masyarakat berupaya menciptakan lapangan kerja sendiri, yakni dengan membuka bisnis, baik secara online maupun 
offline. Berbagai macam bisnis mulai dikelola di Indonesia, mulai dari bisnis di bidang pertanian, produksi bahan mentah, manufaktur, konstruksi, transportasi, komunikasi, perdagangan besar atau kecil, finansial dan jasa. Tujuan bisnis-bisnis tersebut adalah untuk menghasilkan keuntungan dengan menjualkan barang atau jasa sesuai dengan prinsip ekonomi jual-beli.

Maraknya masyarakat yang mulai terjun dalam dunia bisnis membuat persaingan dalam dunia bisnis semakin meningkat, ketat dan kompleks. Banyak perusahaan memperebutkan posisi dalam persaingan bisnis dengan tujuan mencari keuntungan. Dalam dunia bisnis banyak persaingan manajemen perusahaan yang harus memiliki keahlian secara kuat dan peka terhadap persaingan, agar mampu mengantisipasi dan membantu persaingan bisnis sehingga dapat menjalankan suatu perusahaan secara efektif dan efisien (Fauroni, 2011).

Setiap pebisnis berkonsentrasi untuk mendapatkan peringkat lebih baik di mata masyarakat dari sekedar bertahan hidup. Perusahaan tidak sekadar berusaha mendapatkan konsumen yang baru, tetapi juga berupaya dan bersungguh-sungguh untuk mempertahankan konsumen yang telah diperoleh. Keinginan konsumen juga menjadi hal berharga yang menjadi perhatian perusahaan. Untuk meningkatkan konsumen pebisnis memperhatikan strategi dalam penjualan maupun penawaran produk atau jasa yang dikelola. Strategi bisnis harus mencakup kualitas dari barang atau jasa yang ditawarkan, target pemasaran, memiliki kreativitas dan inovasi, tingkat promosi yang efektif, mampu memanfaatkan teknologi yang ada, serta manajemen bisnis yang baik. Saat ini ada banyak tempat bisnis yang menawarkan suasana bersantai atau sekedar menjadi tempat melaksanakan rapat (meeting) dan banyak tawaran kenyamanan kepada konsumen untuk meningkatkan kunjungan dan memperoleh keuntungan yang maksimal. Perusahaan memahami bahwa pelanggan cenderung memilih tempat yang lebih nyaman sesuai dengan harapan (Kotler \& Amstrong, 2012).

Setiap usaha atau bisnis yang didirikan tentunya menginginkan perolehan keuntungan yang sebesar-besarnya dengan pengeluaran yang seminimal mungkin. Hal ini juga berlaku pada bisnis café, kedai dan sejenisnya. Banyaknya pesaing dalam bisnis ini juga menjadi tantangan utama yang harus dihadapi, terutama dalam bidang pemasaran. Untuk menarik minat konsumen agar melakukan pembelian, pengelola bisnis menerapkan strategi STP (Segmenting, Targeting, Positioning) sesuai kondisi saat ini (Tjahjono et al., 2013).

Pemasaran merupakan suatu kegiatan utama yang dijalankan oleh pebisnis dalam upaya mempertahankan kelangsungan bisnisnya, mengembangkan dan menerima manfaat. Keberhasilan atau kegagalan membatasi tujuan bisnis pada keterampilan kewirausahaan dalam memasarkan, memproduksi dan mengelola keuangan dalam dunia bisnis. Kemampuan pengusaha untuk menggabungkan tugas tersebut juga diperlukan secara berurutan agar bisnis dapat berjalan dengan lancar (Kotler \& Amstrong, 2012).

Peran strategi pemasaran dalam bisnis cafe yang tepat tidak sebatas positioning sebagai cara mendapatkan perhatian konsumen, namun ada 2 strategi yang dilakukan untuk mengembangkannya, yaitu strategi segmentasi dan target pasar sasaran, serta cara yang diinginkan pebisnis. Positioning berarti sejauh mana suatu titik layanan didefinisikan oleh konsumen melalui apa yang ada di benak mereka saat menyebutkan suasana tempat (Barney \& Hesterly, 2015). Seperti yang dilakukan oleh Pan Java, sebuah perusahaan jasa yang bergerak di bidang caffee dan Meals.

Dalam meningkatkan kualitas bisnis, bisnis café perlu memperhatikan strategi dalam pemasaran. Strategi ini memiliki tiga aspek, yaitu segmenting, targeting dan positioning. Melalui 
tiga strategi ini pebisnis dapat melihat pasar yang akan ditargetkan. Namun demikian, tetap perspektif perusahaan terhadap pasar yang membedakan perusahaan dari pesaingnya. Segmentasi pasar sangat membantu sebuah perusahaan untuk bisa memilih dan mengembangkan suatu produk (Darmayani, 2014).

\section{Strategi Komunikasi}

Strategi adalah pendekatan secara keseluruhan yang berkaitan dengan gagasan, perencanaan dan eksekusi sebuah aktivitas dalam kurun waktu tertentu. Di dalam strategi yang baik terdapat koordinasi tim kerja, memiliki tema mengidentifikasi faktor pendukungnya sesuai dengan prinsip-prinsip pelaksanaan gagasan secara rasional, efesiensi dalam pendanaan dan memiliki taktik untuk mencapai tujuan secara efektif (Cangara, 2013).

Strategi menunjukkan arahan umum yang hendak ditempuh oleh organisasi untuk mencapai tujuannya. Strategi ini merupakan rencana besar dan rencana penting. Setiap organisasi ingin mencapai tujuannya. Setiap organisasi yang dikelola secara baik memiliki strategi, walaupun tidak dinyatakan secara eksplisit. Strategi merupakan faktor yang paling penting dalam mencapai tujuan perusahaan, keberhasilan suatu usaha tergantung pada kemampuan pemimpin yang bisa dalam merumuskan strategi yang digunakan. Strategi perusahaan sangat tergantung dari tujuan perusahaan, keadaaan dan lingkuangan yang ada. Strategi adalah keseluruhan upaya, dalam rangka mencapai sasaran dan mengarah kepengembangan rencana marketing yang terinci. Strategi sangat penting untuk diterapkan dalam perusahaan agar tujuan dari perusahaan agar bisa tercapai.

Sebuah strategi komunikasi hendaknya mencakup segala sesuatu yang dibutuhkan untuk mengetahui bagaimana berkomunikasi dengan khalayak sasaran. Strategi komunikasi mendefinisikan khalayak sasaran, berbagai tindakan yang akan dilakukan, mengatakan bagaimana khalayak sasaran akan memperoleh manfaat berdasarkan sudut pandangnya, dan bagaimana khalayak sasaran yang lebih besar dapat dijangkau secara lebih efektif. Menurut (Effendi, 2015) ada empat tujuan dalam strategi komunikasi, yaitu (1) To Secure Understanding yaitu untuk memastikan bahwa terjadi suatu pengertian dalam berkomunikasi, (2) To establish acceptance yaitu bagaimana cara penerimaan itu terus dibina dengan baik, (3) To motivate action, yaitu pengingatan untuk memotivasinya, dan (4) To goals which communicator sought to acieve.

Namun demikian, terdapat beberapa hal yang harus diperhatikan ketika menyusun strategi komunikasi. Hal-hal tersebut adalah memperhatikan segala kelebihan dan kekurangan yang melekat pada komponen-komponen komunikasi. Pertama, Komunikator. Indikator yang paling penting dalam komunikator adalah kreabilitas yaitu menyangkut kepercayaan dan keahlian. Kepercayaan dan keahlian yang dimaksud adalah dari aspek keilmuan dan pengetahuan sesuai dengan apa yang akan disampaikan. Pada seorang komunikator yang kredibel harus memiliki beberapa ciri, yaitu memiliki energi tinggi dan toleransi terhadap tekanan, percaya diri, kendali internal, kestabilan dan kematangan emosional, integritas pribadi, motivasi kekuasaan dan orientasi kepada keberhasilan.

Kedua, Pesan. Isi pesan dalam strategi komunikasi sangat menentukan aktivitas komunikasi yang dilancarkan dapat efektif, maka pesan yang disampaikan harus (a) harus dirancang dan disampaikan sedemikian rupa sehingga dapat menarik perhatian sasaran yang dimaksud, (b) harus menggunakan tanda-tanda yang tertuju pada pengalaman yang sama antara 
sumber dan sasaran, sehingga sama-sama dipahami dan dimengerti, (c) harus membangkitkan kebutuhan pribadi pihak sasaran dan menyarankan beberapa cara untuk memperoleh kebutuhan itu, dan (d) harus menyarankan dan sesuatu jalan untuk memperoleh kebutuhan yang layak bagi situasi kelompok dimana sasaran berada pada saat digerakkan untuk memberikan tanggapan yang dikehendaki.

Ketiga, Media atau Saluran. Dalam strategi komunikasi segala sesuatu harusnya dikorelasikan dengan komponen-komponen yang merupakan jawaban dari pertanyaan yang dirumuskan Harold D. Lasswel, yaitu who says what in wich channel to whom with what effect (Effendi, 2015). Rumus di atas tampak sederhana, tetapi jika dikaji lebih jauh pertanyaan 'efek-efek apa yang diharapkan' secara implisit mengandung pertanyaan lain yang perlu dijawab dengan seksama, yaitu (1) When (kapan dilaksanakannya), (2) How (bagaimana melaksanakannya), dan (3) Why ( mengapa dilaksanakan demikian).

Dalam menyusun strategi komunikasi, ada tahapan-tahapan tertentu yang perlu dijalankan oleh suatu perusahaan atau lembaga. Satu, Segmentasi. Segmentasi dapat didefinisikan sebagai proses membagi pasar untuk suatu produk ke dalam kelompok/komunitas yang lebih kecil, dimana para anggota masing-masing kelompok mempunyai kesamaan persepsi, keinginan dan motivasi yang sama terhadap faktor-faktor yang mempengaruhi permintaan (Hasan, 2014). Dua, Targeting. Dalam konteks STP (segmenting, targeting dan positioning) berhubungan erat dengan adanya media yang dapat digunakan untuk menjangkau kelompok atau segmen baru. Targeting mempunyai dua fungsi sekaligus yaitu menyeleksi pasar sasaran sesuai dengan kriteria-kriteria tertentu (selecting) dan menjangkau pasar sasaran tersebut (reaching) untuk mengkomunikasikan nilai (Kasali, 2011). Tiga, Positioning, yakni strategi yang berusaha menciptakan diferensiasi yang unik dalam benak pelanggan sasaran, sehingga terbentuk citra (image) merek atau produk yang lebih unggul dibandingkan merek/produk pesaingnya (Tjiptono \& Chandra, 2012).

\section{Brand Image}

Citra merek adalah persepsi konsumen terhadap perusahaan atau produk. Citra tidak dapat ditanamkan dalam pikiran konsumen dalam semalam atau disebarkan melalui satu media saja. Sebaliknya, citra harus disampaikan melalui tiap sarana komunikasi yang tersedia dan disebarkan secara terus menerus karena tanpa citra yang kuat sangatlah sulit bagi sebuah perusahaan untuk menarik pelanggan baru dan mempertahankan pelanggan yang sudah ada (Kotler \& Amstrong, 2012).

Citra merek sebagai bagian dari merek yang dapat dikenali namun tidak dapat diucapkan, seperti lambang, desain huruf atau warna khusus, atau persepsi pelanggan atas sebuah produk atau jasa yang diwakili oleh merek-nya. Dapat juga dikatakan bahwa brand image merupakan konsep yang diciptakan oleh konsumen karena alasan subyektif dan emosi pribadinya. Jadi, kesimpulan brand image (citra merek) merupakan gambaran yang atau kesan yang ditimbulkan oleh suatu merek dalam benak pelanggan. Penempatan citra merek di benak konsumen harus dilakukan secara terus menerus agar citra merek yang tercipta tetap kuat dan dapat diterima secara positif. Ketika sebuah merek memiliki citra yang kuat dan positif di benak konsumen, maka merek tersebut akan selalu diingat dan kemungkinan konsumen untuk membeli merek tersebut sangat besar (Ferrinadewei, 2018). 
"Brand image refers to the schematic memory of a brand" (citra merek mengacu pada skema ingatan dari suatu brand). "It contains the target market's interpretation of the product's attributes, benefits usage situations, users, and manufacturer/marketer characterristics. It is what people think of and fell when they hear or see a brand name".

Memori tersebut mengandung interpretasi produk dari atribut, manfaat, kegunaan, situasi penggunaan, pengguna, dan karakteristik pabrikan. Itulah mengapa orang-orang berpikir dan merasakan apa yang mereka dengar atau lihat dari suatu nama merek (Hawkins \& Mothersbaugh, 2010).

Menurut Keller (dalam Leliga, 2013), di dalam brand image terdapat 3 dimensi yang merangkai sebuah brand image. Pertama, Brand Strength, yaitu seberapa sering seseorang terpikir tentang informasi suatu brand ataupun kualitas dalam memproses segala informasi yang diterima konsumen. Hal ini dapat diukur dari empat indicator, yaitu kemudahan mengucapkan nama merek, kemudahan mengingat logo, penyampaian produk dan layanan sesuai dengan informasi pemasaran di brosur atau website dan konsistensi implementasi penyampaian layanan. Kedua, Brand Favorability, yakni kesukaan terhadap brand, kepercayaan dan perasaan bersahabat dengan suatu brand, serta akan sulit bagi brand lain untuk dapat menarik konsumen yang sudah mencintai brand tersebut. Brand favorability dapat diukur dari lima indicator, yaitu kelengkapan dan terawatnya fasilitas yang ada, fasilitas yang ada dapat berfungsi dengan baik, pelayanan yang profesional dari karyawan, gedung yang nyaman dan aksesnya yang mudah. Ketiga, Brand Uniqueness, yaitu membuat kesan unik dan perbedaan yang berarti di antara brand lain serta membuat konsumen "tidak mempunyai alasan untuk tidak" memilih brand tersebut. Terdapat dua indikator dalam brand uniqueness, yaitu memberikan kemudahan dan produk yang berbeda dan mengutamakan privasi konsumen.

\section{Metode Penelitian}

Penelitian ini mennggunakan motode penelitian kualitatif. Metode kualitatif deskriptif mengacu pada pengumpulan data berupa observasi, wawancara dan peneliti bertindak sebagai pengamat. Peran peneliti di sini adalah selama penelitian berlangsung peneliti bebas mengamati, menjelajah dan menemukan wawasan baru dari objek penelitiannya (Zainuddin, 2017).

Teknik analisis data yang digunakan dalam penelitian ini adalah analisis deksriptif kualitatif, yaitu data yang diperoleh dari hasil wawancara dan dokumentasi dihimpun dan dideskripsikan. Pada penelitian ini penarikan kesimpulan akan dilakukan dengan cara menganalisis dan mengidentifikasi data-data yang telah terkumpul terkait dengan permasalahan yang diteliti, dan hasil analisis dari penelitian merupakan jawaban dari permasalahan yang diteliti mengenai strategi segmenting, targeting dan positioning Pan Java dalam membentuk brand image.

\section{Hasil dan Pembahasan}

Dalam menyusun strategi komunikasi, sebuah perusahaan atau lembaga, terutama yang bergerak di bidang bisnis perlu memperhatikan beberapa tahapan yang harus dilakukan, yaitu segmenting, targeting, dan positioning. Ini memberikan gambaran bahwa strategi pembentukan citra atau merek sebuah lembaga tidak dilakukan dengan sembarang langkah. Ada langkah-langkah tertentu yang harus dilakukan sehingga dapat memperoleh hasil yang maksimal. 
Demikian pula yang dilakukan oleh Kafe Pan Java dalam merumuskan strategi komunikasi untuk membentuk brand image. Kafe yang terletak di Mulyoagung Malang ini sangat memperhatikan tiga tahapan yang dimaksud sebelumnya, yaitu segmenting, targeting, dan positioning.

\section{Segmenting}

Pada tahapan ini Kafe Pan Java berfokus pada tiga variabel segmentasi di mana setiap variabel memiliki kategori segmen yang ingin dituju seperti segmentasi demografis perusahaan memfokuskan konsumen untuk pemasaran yang mayoritas menengah ke atas. Persaingan dalam bisnis yang bergerak di bidang wisata sangatlah ketat, sehingga menuntut kawasan wisata untuk melaksanakan strategi yang terarah agar mampu menghadapi dan memenangkan persaingan antar kompetitor yang sejenis. Segmentasi pasar merupakan cara bagi cafe/desa wisata untuk mengelompokkan pasar yang bersifat heterogen ke dalam bagian pasar yang bersifat homogen. Dalam hal ini terdapat 3 (tiga) segmentasi yang diterapkan di Pan Java, yaitu Dasar Penentuan Segmen Pasar, Segmentasi Psikografis, dan Segmentasi Perilaku.

Segmentasi pasar pada dasarnya memiliki sifat dan karakteristik yang berbeda-beda. Oleh karena itu akan sulit bagi cafe/desa wisata untuk mempromosikan tempatnya tanpa melakukan segmentasi pasar dan menyeleksi pasar sesuai dengan kemampuan perusahaan. Segmentasi pasar merupakan cara bagi cafe/desa wisata untuk mengelompokkan pasar yang bersifat heterogen ke dalam bagian pasar yang bersifat homogen. Dalam pelaksanaannya, desa wisata harus dapat menentukan dan memilih pasar yang sesungguhnya dan benar-benar prospek untuk tempat dan kenyamanan yang ditawarkan, sehingga pasar dapat terpenuhi kebutuhannya dan pemasaran dapat berjalan dengan efektif.

Dalam dasar penentuan segmen pasar Pan Java memiliki kriteria-kriteria tertentu agar dapat menempatkan pelayanannya dalam posisi yang terbaik. Kriteria yang digunakan menggunakan beberapa dasar. Pertama, Segmentasi Demografis. Dalam segmentasi demografis, Pan Java Mulyoagung membagi pembeli menjadi kelompok yang berbeda berdasarkan: (1) usia dari umur 18 tahun-50 tahun ke atas usia pembeli yang dituju telah cukup matang dan mampu datang untuk berkunjung ke Pan Java, (2) Pendidikan mahasiswa, pengawai, pengusaha, keluarga dan PNS. Mengenai pendidikan, Pan Java menargetkan konsumen terpelajar, pegawai, dan para pebisnis maupun keluarga. Kedua, Segmentasi Psikografis. Dalam segmentasi psikografis, Pan Java lebih mengarah kepada gaya hidup adalah pola hidup seseorang di dunia yang diekspresikan dalam aktifitas, minat dan opininya. Gaya hidup menunjukan keseluruhan diri seseorang dalam berinteraksi dengan lingkungannya. Gaya hidup menggambarkan seluruh pola seseorang dalam beraksi dan berinteraksi di dunia dimana para pembeli atau konsumen suka nongkrong dan mengikuti trend yang instagramble. Ketiga, Segmentasi Perilaku. Dalam segmentasi perilaku, Pan Java lebih mengarah kepada respon para konsumen atau pembeli apakah konsumen merasa senang dan nyaman dengan suasana dan pelayanan ketika berada di Pan Java.

\section{Targeting}

Dalam menentukan strategi target pasar, Pan Java Mulyoagung menggunakan strategi penetapan sasaran terkonsentrasi (concentrated targeting strategy). Strategi ini hanya memusatkan usaha pemasarannya pada satu kelompok pembeli saja atau biasanya perusahaan 
memilih satu segmen pasar dari pasar untuk memusatkan upaya-upaya pemasaranya. Adapun yang menjadi target pasar dari Pan Java adalah masyarakat tingkat menengah keatas seperti Pegawai Negeri Sipil (PNS), pegawai bank, pengusaha, mahasiswa, pelajar, ataupun dosen.

Perusahaan dapat memilih satu segmen atau lebih untuk dimasuki. Dalam menentukan strategi target pasar, Pan Java Mulyoagung menggunakan strategi penetapan sasaran terkonsentrasi (concentrated targeting strategy). Strategi ini hanya memusatkan usaha pemasarannya pada satu kelompok pembeli saja atau biasanya perusahaan memilih satu segmen pasar dari pasar untuk memusatkan upaya-upaya pemasaranya.

\section{Positioning}

Positioning sangatlah penting bagi semua perusahaan seperti halnya yang dilakukan oleh Pan Java Mulyoagung, di mana cafe tersebut mengusung tema adat dan budaya Jawa serta melihat potensi lahan desa yang dimanfaatkan agar bisa menjadi pemasukan bagi masyarakat sekitar. Dengan demikian, dapat dikatakan bahwa model strategi segmenting, targeting, dan positioning Pan Java dalam membentuk Brand Image adalah di mana segmentasi berfokus pada tiga variabel, yang pada tiap variabel memfokuskan konsumennya pada pemasaran mayoritas masyarakat menengah keatas, sehingga Targeting dari Pan Java juga kepada masyarakat yang tingkat perekonomiannya level menengah keatas, seperti Pegawai Negeri Sipil (PNS), Pegawai Bank, Dosen, Mahasiswa, Pelajar, Pengusaha dan lain-lain. Untuk Positioning nya sendiri dikelilingi oleh sawah sehingga menghasilkan hawa lingkungan yang menyejukan, selain itu model arsitektur bangunan yang unik, menjadikan Pan Java, lokasi ideal untuk di kunjungi.

Sebelum terdampak Covid-19, strategi pemasaran yang digunakan Pan Java adalah menyediakan berbagai macam produk Pan Java di tiga zona, yaitu Warung Tani, Kopi Tani, dan Warung Kasemo. Ketika zona ini memiliki berbagai macam makanan dan minuman yang disediakan terutama produk minuman seperti kopi. Jenis kopi yang disajikan di sini bermacam-macam, seperti kopi pahit kental,kopi pahit, kopi biasa, kopi tanpa gula, kopi susu, kopi susu tanpa gula, green tea dan lain-lain. Disediakan pula makanan rumahan seperti ceker pedas, pindang goreng, sayur daun singkong.

Selain produk, keberadaan lokasi sangat penting dalam pemasaran. Lokasi adalah suatu usaha/upaya agar suatu produk dapat tersedia di tempat-tempat yang memudahkan konsumen membelinya setiap saat konsumen membutuhkan. Tempat dinilai dari kestrategisan lokasi, kemudahan dalam melakukan reservasi, dan kemudahan dalam melakukan delivery, kesediaan parkir, dan mudah dalam mencarinya. Strategi tempat adalah strategi yang didalamnya terdapat kegiatan yang dilakukan perusahaan serta membawa sebagian produk ke pasar agar produsen bekerjasama dengan perantara. Strategi tempat yang dilakukan pan java yaitu memiliki lokasi yang cukup strategis yaitu dekat dengan komplek cafe dan juga dekat dengan kampus.

Selain strategi lokasi, Pan Java juga melibatkan saluran distribusi fisik maupun elektronik dalam proses ini. Konsumen menilai lokasi Pan Java sangat strategis dan mudah dicapai, begitu pula dengan kenyamanan dan kebersihan Pan Java. Dengan kata lain konsumen merasa puas dengan kenyamanan dan kebersihan Pan Java. Untuk dapat menikmati makanannya, konsumen dapat langsung datang ke Pan Java atau konsumen dapat menggunakan saluran elektronik melalui telepon untuk mendapatkan pelayanan delivery service, dan juga melalui gofood. Pan 
Java berlokasi tepat pada kompleks Dau sehingga mudah dicari, tempat parkir yang memadai sehingga memudahkan customer.

Tidak kalah dengan dua aspek sebelumnya, harga juga menjadi salah satu elemen dari marketing mix yang digunakan perusahaan untuk mencapai sasaran pemasarannya. Setiap perusahaan yang ingin mendapatkan laba selalu menghadapi masalah dalam penetapan harga produk. Harga tergantung pada kebijakan perusahaan, tetapi tentu saja dengan mempertimbangkan berbagai hal. Harga dikatakan mahal, murah, atau biasa-biasa saja bagi setiap individu. Hal ini tergantung dari individu yang dilatarbelakangi oleh lingkungan kehidupan dan kondisi individu.

Pan Java sangat memperhatikan permintaan beserta persepsi nilai konsumen untuk harga produk yang dihasilkannya. Jika perusahaan menetapkan harga lebih tinggi dari persepsi nilai konsumen, maka diramalkan permintaan sedikit atau dapat dikatakan tidak akan banyak terjual. Sebaliknya jika perusahaan menetapkan harga yang lebih rendah dari persepsi nilai konsumen, maka diramalkan permintaan lebih banyak tetapi dapat menghasilkan pendapatan yang tidak sesuai dengan yang diharapkannya.

Langkah selanjutnya adalah Promotions (Promosi). Kegiatan pemasaran tidak hanya sekedar memasarkan produk yang bagus, menetapkan harga yang menarik dan membuat produk tersebut terjangkau oleh pelanggan, namun perusahaan juga perlu mengkomunikasikan dan mempromosikan produknya secara efektif pada konsumen. Lebih daripada itu, kegiatan pemasaran atau promosi adalah untuk menjalin interaksi antara perusahaan dengan konsumen (Kusniadji, 2017). Dalam hal ini promosi yang digunakan rata-rata menggunakan media sosial, beberapa juga bekerjasama dengan grab/go food. Selain itu, promosi dilakukan oleh pelanggan yang telah mengenal cafe kepada calon pelanggan yang belum mengetahui melalui penyampaian informasi secara lisan.

Strategi pemasaran Pan Java dilakukan melalui iklan media digital seperti media sosial Instagram. Media sosial ini dpilih mengingat banyak masyarakat sekarang yang menggunakan instagram dalam kehidupan sehari-hari untuk mendapatkan informasi yang dibutuhkan. Instagram Pan Java setiap hari meng-update informasi yang bertujuan untuk menginformasikan penyampaian pesan, menciptakan dan menarik minat pelanggan dan calon pelanggan secara mudah dengan orientasi yang luas Pan Java juga masih menggunakan facebook untuk iklan karena sekarang masih banyak juga masyarakat yang menggunakan facebook untuk mendapatkan informasi yang dibutuhkan. Dalam facebook dengan nick name cafe terdapat halaman yang menginformasikan akan cafe yang dicari seperti alamat, produk, kontak, promosi, foto dan video konten cafe dan juga dokumentasi serta ulasan dari pengunjung yang pernah berkunjung ke café tersebut.

Akan tetapi, Covid-19 yang semakin menyebar membuat banyak bisnis mengalami kerugian. Adanya batasan keluar rumah dan karantina masing-masing membuat pelanggan semakin terasing. Krisis yang sedang berlangsung menekan para pebisnis UKM untuk terus bertahan. Ada sebagian bisnis yang justru meningkat, sedangkan yang lainnya berjuang untuk hanya satu atau dua penjualan Ini berarti, sebagai pebisnis harus memikirkan kembali upaya apa yang akan dilakukan agar membuat bisnis tetap berjalan. Maka Pan Java sebelum terdampak Covid-19 dan sesudah terdampak Covid-19 berdasarkan strategi Positioning Menurut Product, Place, Promotion, dan Price untuk produk nya sendiri sebelum pandemi Covid-19, menyediakan beraneka ragam makanan siap saji, dan juga berbagai minuman tanpa adanya pembatasan 
tertentu, sedangkan setelah adanya pandemi, membatasi jumlah produk yang di keluarkan karena mengikuti sistem $50 \%$ dari jumlah normal.

\section{Strategi Kafe Pan Java dalam Membentuk Brand Image}

Dalam membentuk brand image, Kafe Pan Java menerapkan strategi penggunaan produk lokal. Pan Java menerapkan konsep dan memperkenalkan produk secara langsung pada konsumen atau pelanggan dengan memanfaatkan media sosial seperti instagram dan facebook. Dalam membentuk brand image, Pan Java melakukannya dengan nama merek dan logo serta simbol. Nama merek, logo dan simbol yang digunakan sangat penting untuk mengembangkan produk lokal dalam dunia usaha.

Brand image yang dibentuk Kafe Pan Java dianalisis berdasarkan teori dari Keller (dalam Leliga, 2013) di mana brand image dirangkai menjadi 3 dimensi pembahasan, yaitu Brand Strenght, Brand Favorability, dan Brand Uniqueness. Brand Streght yang dibangun oleh Pan Java adalah dengan membentuk Cafe dan Restaurant yang memiliki konsep yang kuat yakni mengangkat model arsitektur jawa kuno yang dipadukan dengan berbagai fasilitas penunjang yang mengikuti perkembangan jaman, sehingga dapat memberi kesan kepada pengunjung mengenai ekspor budaya lokal yang unik dan memberikan kesan privat kepada pengunjung. Karena memiliki fasilitas Gazebo yang terpisah, maka bagi pengunjung yang ingin memiliki quality time bersama keluarga dapat terjaga. Selain itu nama Pan Java yang berarti Panorama Alam Nusantara Jawa mudah diingat karena mengusung kosep budaya local dan sangat jarang dikonsepkan oleh kafe atau restoran lain.

Pada dimensi Brand Favorability, Pan Java sendiri membentuknya dengan konsep yang berdasar pada 5 faktor, yakni kelengkapan dan terawatnya fasilitas yang ada, dimana Pan Java memiliki fasilitas penunjang selain sebagai tempat ngopi santai dan tempat quality time bersama keluarga, Pan Java juga memberikan kesempatan kepada konsumen yang suka berburu spot foto yang bagus, dengan menyediakan berbagai spot foto unik dan tetap menekankan pada konsep yang asri dan ramah bagi pengunjung, selain itu fasilitas pendukung lain seperti kolam pemancingan memberikan kesan yang baik kepada konsumen, dimana konsumen bisa sekaligus rekreasi dengan memancing dan menikmatiti hasil pancingan mereka, sehingga pengunjung dapat mencapai kepuasan terhadap hasil usaha dan jeri payah mereka sendiri. Brand Uniqueness dari Pan Java adalah konsep bangunannya yang mengusung model Jawa kuno dengan perpaduan fasilitas pendukung seperti tempat pemancingan, area outdoor, indoor, Gazebo, serta spot foto yang unik menjadikan pengunjung tertarik untuk mencoba model café yang calsic dengan perpaduan nuansa tradisional budaya daerah setempat.

\section{Faktor-Faktor yang Mempengaruhi Kafe Pan Java dalam Membentuk Brand Image}

Strategi yang diterapkan Pan Java dalam membentuk citra (brand image) tidak terlepas dari faktor pendukung dan penghambat. Jika dilihat dari faktor pendukung, ada dua faktor pendukung yang mempengaruhi penerapan strategi STP Pan Java, yaitu faktor pendukung yang berasal dari dalam (internal) dan faktor pendukung yang berasal dari luar (eksternal). Faktor pendukung internal adalah dukungan yang berasal dari dalam perusahaan baik dari pemimpin menejer dan semua anggota yang berhubungan dengan Pan Java untuk bisa membangun kerja sama dalam mengembangkan usaha. Dari hasil wawancara disimpulkan bahwa faktor pendukung dari dalam Pan Java itu sendiri adalah berupaya kerja sama antara karyawan dan pihak Pan Java. 
Faktor pendukung eksternal merupakan dukungan dari luar Pan Java demi kelancaran suatu usaha. Dukungan eksternal ini dialami oleh Pan Java berdasarkan hasil wawancara dengan karyawan. Dari hasil wawancara dapat disimpulakan bahwa dukungan dari luar Pan Java konsumen sudah membatu mempromosikan Pan Java dan produk yang ada di Pan Java seperti makanan yang mereka pesan dan di muat ke media sosial merek.

Namun demikian, penerapan strategi STP Pan Java juga tidak lepas dari kendala, baik internal mupun eksternal. Faktor penghambat internal berbentuk penolakan baik berupa sikap dan tindakan yang datangnya dari dalam Pan Java yang akan menghambat proses perkembangan Pan Java. Hambatan internal yang di alami Pan Java perupa keterbatasan karyawan dan kurangnya update di media sosial. Sementara itu, faktor penghambat eksternal merupakan penolakan atau penghambat yang datangnya dari luar Pan Java. Yang terhitung sebagai faktor penghambat dari luar ini adalah pandemi Covid-19 yang mengakibatkan banyak perusahan atau UKM mengalami penurunan penghasilan.

\section{Kesimpulan}

Segmentasi yang dilakukan oleh Pan Java Cafe menggunakan beberapa dasar, di antaranya yaitu segmentasi demografis, segmentasi psikografis dan segmentasi perilaku. Dalam menentukan strategi pemilihan pasar sasaran atau target pasar Pan Java menggunakan strategi Penetapan Sasaran Terkonsentrasi (Concentrated Targeting Strategy) di mana strategi ini hanya memusatkan usaha pemasaran pada satu kelompok pembeli saja yaitu konsumen dengan tingkat perekonomian menengah keatas seperti Pegawai Negeri Sipil (PNS), pegawai bank, mahasiswa, pelajar, guru, dosen, dan para wisatawan. Dalam aspek produk, Pan Java menyediakan menu-menu sederhana yang sangat familiar untuk konsumen yaitu berupa berbagai macam olahan kopi dan makanan-makanan ringan yang cocok untuk bersantai. Di area prasmanan pun, makanan yang disajikan adalah makanan-makanan tradisional khas rumahan. Sehingga pengunjung dapat tetap merasakan suasana rumah dengan nuansa yang berbeda. Dari aspek tempat, lokasi Pan Java sudah sangat strategis, memiliki lahan parkir yang luas, dan akses yang mudah dijangkau. Ditambah lagi, lingkungan sekitar dikelilingi banyak cafe dan juga dekat dengan lingkungan kampus. Faktor-faktor yang mempengaruhi Pan Java dalam membentuk brand image adalah kerja sama tim yang baik antar pekerja atau pegawai sehingga dapat menjalankan usaha sebagaimana mestinya. Sementara yang menjadi penghambat adalah susahnya pelayanan akibat konsumen yang menumpuk dan bencana Covid-19.

\section{Daftar Pustaka}

Barney, J. B., \& Hesterly, W. (2015). Strategic Management and Competitive Advantage. Person/Prentice Hall.

Cangara, H. (2013). Perencanaan \& Staretgi Komunikasi. Raja Grafindo Persada.

Darmayani, A. (2014). Strategi Pemasaran Kerajinan Buah Kering untuk Meningkatkan Nilai Ekspor pada UD. Indo Nature, LOMBOKâNTB. Jurnal Administrasi Bisnis S1 Universitas Brawijaya, 11(1), 1-10.

Effendi, O. U. (2015). Ilmu komunikasi Teori dan Praktek. PT Remaja Rosdakarya.

Fauroni, R. L. (2011). Etika Bisnis Dalam Al Qur'an. Pustaka Pesantren.

Ferrinadewei, E. (2018). Merek Dan Psikologi Konsumen, Implikasi Pada Strategi Pemasaran. Graha Ilmu.

Hasan, A. (2014). Marketing dan Kasus-Kasus Pilihan. CAPS.

Hawkins, D. I., \& Mothersbaugh, D. L. (2010). Consumer Behavior. Mcgraw-Hill. 
Kasali, R. (2011). Membidik Pasar Indonesia Segmenting, Targeting dan Positioning. Gramedia. Kotler, P., \& Amstrong, G. (2012). Manajemen Pemasaran. Alfabeta.

Kusniadji, S. (2017). Strategi Komunikasi Pemasaran dalam Kegiatan Pemasaran Produk Consumer Goods (Studi kasus Pada PT Expand Berlian Mulia Di Semarang. Jurnal Komunikasi, 8(1), 83-98.

Leliga, F. J. (2013). Analisa Pengaruh Brand Image Terhadap Customer Loyalty dengan Customer Satisfaction sebagai Mediator pada The Dreamland Luxury Villas and SPA, Bali. Jurnal Hospitality Dan Manajemen Jasa, 1(1).

Tjahjono, A., Semuel, H., \& Brahmana, R. K. M. R. (2013). Analisa Markerting Mix, Lingkungan Sosial, Psikologi Terhadap Keputusan Pembelian Online Pakaian Wanita. Jurnal Manajemen Pemasaran Petra, 1(2), 1-9.

Tjiptono, F., \& Chandra, G. (2012). Pemasaran Strategik. Edisi 2. Andi Offset.

Zainuddin. (2017). Metode Penelitian Hukum. Sinar Grafika. 